\title{
The McGill University Library Catalogue of 1876: A Preliminary Statistical Analysis
}

\author{
By Peter F. McNally \\ Associate Professor, Graduate School of Library and Information Studies \\ and \\ Kevin Gunn \\ Library, Catholic University of America, Washington, D.C.
}

Determining the early history of the McGill Libraries poses certain difficulties. Only with the appointment of Charles H. Gould as University Librarian in 1892 and the opening of Redpath Library the following year were detailed administrative records maintained. For the preceding fifty years or so, our knowledge of library development is vague and sketchy, due to incomplete documentation. ${ }^{1}$

Although vestigial remains can be found of a library dating back to the 1840 s, Sir John William Dawson was convinced that on his arrival at McGill in 1855 there was no library. One of his first undertakings as principal was to serve also as librarian from 1855 to 1857 . Indeed, he went so far as to have the library located in his own office from 1860 to 1862 . Over the succeeding decades, the library improved slowly but steadily: in 1862 it found a tranquil home in the newly built west wing of the Arts Building (Molson. Hall) where it remained until the opening of Redpath Library in 1893; from 1857 to 1882, Charles F. A. Markgraf, a professor of German, provided consistent and dedicated service as librarian; largely through the support of benefactors the collection grew constantly larger and stronger.

For this period a primary document, which has been largely overlooked, is the Catalogue of Authors published in $1876 .{ }^{2}$ It provides a permanent record of the collection as it was in the mid-1870s and permits its assessment in a way that is both unique and convincing. In addition, the catalogue permits the collection to be evaluated in relation to the University's teaching and research activities. The fact of the catalogue being only an author listing, plans for a subject catalogue having been cancelled through lack of funds, limits its usefulness only somewhat.

The publication of library catalogues in book form enjoyed great popularity in the nineteenth-century, because they permitted simultaneous perusal by many people in a wide variety of locations. Of course, they were also unpopular in some quarters because they could become voluminous and expenșive for larger collections and because they resisted quick and cheap updating, except through supplementary volumes that broke continuity with the original volume(s).

It is ironic that the McGill catalogue should have been published in 1876, just as the popularity of book catalogues was beginning to wane. In that year, the American Library Association and Library Journal were founded, the first editions of Dewey's classification scheme and Cutter's cataloguing rules were published, and the Library Bureau started issuing standardized cataloguing cards. ${ }^{3}$ As McGill would switch to a card catalogue in 1877 , students of this period are justifiably grateful that the printed catalogue had already appeared.

That said, there are both favourable and unfavourable things to say about the 1876 catalogue. On the one hand, its lack of subject access is a problem as are such things as the entries being very brief; there are inconsistencies on whether continuing publications, like government yearbooks, should be given separate entries for each year or one single entry encompassing a range of years. On the other hand, the catalogue was carefully compiled by 


\section{Notes and Comments}

Professor Markgraf in an exact and reasonably coherent manner. A bonus for researchers is the inclusion with the entries of classification/shelving numbers which, despite some problems, provide helpful insights into the subject orientation of the collection.

Although it is hoped, in time, to provide a more detailed and comprehensive evaluation of the catalogue, the authors of this article are pleased at having an opportunity to present their preliminary results. The number of entries in the catalogue is 5,385 . If one subtracts the 184 'see' references directing readers from unused to used headings, such as 'Canada. Geological Survey of' to 'Geological Survey' one can identify 5,201 titles. The number of monographic titles is 5,098; the number of journal/serial titles is 103. For an academic library collection to have only $1.98 \%$ of its collection as journals seems quite low by twentieth-century standards. Whether this proportion is equally low by nineteenth-century standards is less clear. With 11,021 volumes in the collection, McGill was typical in having significantly more volumes than titles. Of the titles, 3,669 or $70.54 \%$ were in single volumes or copies.

Country and language of publication can provide important insights into the nature of a collection. The 1876 collection reflects the importance of overseas-particularly British-publications, and the relatively weak state of Canadian publishing:

TITLE $\%$

$\begin{array}{lrr}\text { United Kingdom } & 3,023 & 58.12 \\ \text { United States } & 486 & 9.34 \\ \text { Germany } & 414 & 7.96 \\ \text { France } & 358 & 6.88 \\ \text { Canada } & 341 & 6.56 \\ \text { Italy } & 39 & .75 \\ \text { Austria } & 9 & .17 \\ \text { Belgium } & 6 & .12 \\ \text { Greece } & 3 & .06 \\ \text { Sweden } & 2 & .04 \\ \text { Other } & 368 & 7.08 \\ \text { Unknown } & 152 & 2.92 \\ & & \\ \text { TOTAL } & 5,201 & 100\end{array}$

Of the 3,023 titles published in Britain, 194 were Scottish or $6.4 \%$ of the British total and $3.73 \%$ of the overall total. Considering the reputedly Scottish orientation of McGill at this time, the proportion seems rather low. The overwhelming presence of American publications in Canadian academic libraries would be a twentieth-century phenomenon. In all, publications from twenty-six countries were identified.

Publications in 70 languages were noted, a high proportion of these being represented in editions of the Bible. The major languages are as follows: 
TITLES $\%$

$\begin{array}{lrr}\text { English } & 3,722 & 71.56 \\ \text { Latin } & 693 & 13.32 \\ \text { French } & 330 & 6.34 \\ \text { German } & 95 & 1.83 \\ \text { English and French } & 43 & .83 \\ \text { Italian } & 40 & .77 \\ \text { Greek } & 5 & .10 \\ \text { Spanis? } & 4 & .08 \\ \text { Other } & 254 & 4.88 \\ \text { Unknown } & 15 & .29 \\ & & \\ \text { TOTAl } & 5,201 & 100\end{array}$

That English language publications should be overwhelmingly predominant seems less surprising than that Latin should be the second most represented language, albeit a poor second. This reflects, no doubt, the strongly classical nature of the McGill curriculum that would continue into the 1890s; the bulk of these titles was published in Germany. Of the 330 French language titles, 282 were published in France, twenty-three in Canada, and thirteen in Britain. All of the bilingual English-French titles were published in Canada.

Date of publication is also of great relevance and provides valuable insight to the collection. As some multivolume titles were published over many years, thereby fitting into more than one time period, the number of entries for this section rose to 5,254. Date groupings are as follows:

\section{TITLES}

\author{
$1450-1799$ \\ $1800-1849$ \\ $1850-$
}

TOTAL

$\begin{array}{rr}818 & 15.57 \\ 1,491 & 28.38 \\ 2,945 & 56.05\end{array}$

5,254
$\%$

5.57

56.05

100

It is clear that with Dawson's arrival as principal in 1855, a concerted effort was made to acquire current publications for the library. At the same time, the large number of older books reflects the influence of benefactors, such as Peter Redpath, who laid the foundation for the University's outstanding historical rare book collections.

The last, and possibiy most important, topic to be considered is also the most difficult: subject content. As no explanation has been found of the classification system used in the catalogue, the description of its six categories is based upon an analysis carried out by the authors on the titles in each category. It is clear that more work will have to be done on this topic. Although certain inconsistencies appear to have crept into Professor Markgraf's application of the classification system, they are probably no worse than the inconsistencies found in the application of any system. The real problem with this system is that the categories are much too broad: 
TITLES $\%$

$\begin{array}{lrr}\mathrm{A} & 1,459 & 28.05 \\ \mathrm{~A}_{2} & 118 & 2.27 \\ \mathrm{~B} & 560 & 10.77 \\ \mathrm{C} & 937 & 18.02 \\ \mathrm{D} & 1,175 & 22.59 \\ \mathrm{E} & 944 & 18.15\end{array}$

Unknown

8

.15

TOTAL

5,201

100
History, Biography, Geography, Travel, and Politics Fine and Applied Arts

Classical Literature, Philosophy, and Culture

Science, Technology and Medicine

Literature, Philosophy, and Religion

Encyclopaedias, Dictionaries, Atlases, Directories, Bibles, Bibliography, Collections of Essays and

Sermons, Statutes, Law, and Education

For the purposes of comparison, the much more detailed subject classification system used in the library catalogue (4) of the University of Toronto (published in 1857) along with the number of volumes, not titles, in each category is provided below:

$\begin{array}{rrl}\text { VOLUMES } & \% & \\ 135 & 1.95 & \text { Archaeology } \\ 143 & 2.06 & \text { Bibliography \& Literary History } \\ 229 & 3.30 & \text { Biography } \\ 178 & 2.57 & \text { Chemistry \& Chemical Physics } \\ 469 & 6.76 & \text { Divinity } \\ 234 & 3.37 & \text { Encycl. \& Dict. of Science \& Art } \\ 296 & 4.27 & \text { English Literature } \\ 266 & 3.88 & \text { Fine \& Useful Arts } \\ 345 & 4.98 & \text { French, German \& etc. Literature } \\ 141 & 2.03 & \text { Geography, Voyages, \& Travel } \\ 202 & 2.91 & \text { Grammar, Lexicons, \& etc. } \\ 632 & 9.11 & \text { Greek \& Latin Classics } \\ 654 & 9.43 & \text { History, Chronology, Ethnology } \\ 167 & 2.41 & \text { Law, Political Economy \& etc. } \\ 380 & 5.48 & \text { Mathematics, Pure \& Mixed } \\ 734 & 10.59 & \text { Medicine } \\ 130 & 1.87 & \text { Metaphysics, Ethics, Logic \& Rhetoric } \\ 87 & 1.25 & \text { Mineralogy \& Geology } \\ 382 & 5.51 & \text { Natural History } \\ 20 & .29 & \text { Oriental Literature } \\ 1,110 & 16.01 & \text { Transactions \& Periodicals } \\ & & \\ 6,934 & 100 & \text { TOTAL }\end{array}$

Although it is difficult to make direct comparisons between the McGill and Toronto collections--given their different dates of publication, counting methods, and classification systems--one comparison is possible. Science, technology, and medicine in section C of the McGill catalogue and in sections 4, 15, 16, 18, and 19 of the Toronto catalogue are roughly comparable in coverage: 


$\begin{array}{lrlr}\text { McGill (1876) } & 937 & \text { Titles } & 18.02 \% \\ \text { Toronto (1857) } & 1761 & \text { Volumes } & 25.40 \%\end{array}$

As McGill had, however, a separate medical library and therefore relatively few medical books in the main collection, whereas Toronto housed its medical collection in the main library, somewhat different results occur by removing section 16 'Medicine' from the Toronto list:

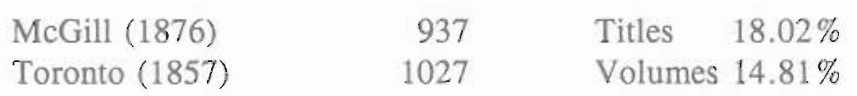

These results suggest that scientific books may account for approximately $15 \%$ of mid-nineteenth- century Canadian academic library collections. Otherwise, the collections of both universities were overwhelmingly weighted in favour of historical, humanistic, political, and legal studies.

In conclusion, this preliminary statistical analysis of the 1876 catalogue is meant to contribute to a larger study of cultural life, reading, and information habits at McGill in the Victorian era. Links between collections, teaching, and research may also be studied. In addition, it is hoped to study further the role played by benefactors in the development of the collections. Finally, this analysis may permit comparison with the collections of other nineteenth-century Canadian academic libraries.

\section{Notes}

1. Peter F. McNally, "The McGill University Libraries." Encyclopedia of Library and Information Science. N.Y. Dekker, 1976, v. 17, p. 311-320. 2. McGili University. Montreal. Library. Catalogue of Authors. Montreai, Lovell, 1876. 322 p.

3. Robert E. Kingery, Book Calalogues. N.Y. Scarecrow, 1963. viii, 330 p. James Ranz. The Primed Book Catalogue in American Libraries, 1723-1900. Chic. ALA. 1964. vii, 144 p.

4. Robert H. Blackbuīi, Evoluion of the Heart: a History of the University of Toromo Library up io /981. Toronto, University of Toronto Librasy, 1989, p. 37-38, 319 . 